\title{
Reference values of parathyroid hormone and vitamin D Hormone by chemiluminescent automated assay
}

\section{Valores de referencia de hormona paratiroidea y vitamina D por método quimioluminiscente automatizado en perros}

\author{
Beatriz Martiarena, ${ }^{1 *}$ Esp, Nadia Kogovsek, ${ }^{5}$ Bioq, Helena Salerni, ${ }^{5}$ Esp, \\ Víctor Castillo, ${ }^{2}$ Ph.D, Georgina Brandi, ${ }^{3} \mathrm{MV}$, Mariela Regonat, ${ }^{1} \mathrm{MV}$, \\ Andrea Visintini, ${ }^{1}$ Esp, Héctor Quintana, ${ }^{4} \mathrm{MV}$, P Otero, ${ }^{5}$ Bioq.
}

Universidad de Buenos Aires, Facultad de Ciencias Veterinarias, Cátedra de Clínica Médica de Pequeños Animales y Hospital Escuela de Medicina Veterinaria, ${ }^{1}$ Servicios de Nefrología, ${ }^{2}$ Endocrinología y ${ }^{3}$ Laboratorio, ${ }^{4}$ Nutrición. Av. Chorroarrín 280, Ciudad Autónoma de Buenos Aires (CP1427) (C.A.B.A.), Argentina. ${ }^{5}$ Hospital General de Agudos "Carlos G.Durand" Servicio de Endocrinología, Av. Diaz Velez 5044 (CP 1405DCS) C.A.B.A. *Correspondencia: bmartiar@fvet.uba.ar

Received: July 2014; Accepted: January 2015.

\begin{abstract}
Objective. Provide reference data for parathyroid hormone 1-84 (PTH 1-84) and 25OH Vitamin D (25OH D) using a new technique. Materials and methods. The hormones were evaluated, in serum, using a third generation automated chemiluminescent method for PTH in a group of 60 adult dogs, clinically healthy, grouped according to age in years in GA: 1 to 5, GB: 6 to 10 and GC: $>10$. Results. Data expressed as average \pm DS were for PTH $(\mathrm{pg} / \mathrm{ml}): 9.3 \pm 2.3 ; 12 \pm 6.3 ; 12.2 \pm 3.7 ;$ and for $25 \mathrm{OH}$ $D(\mathrm{ng} / \mathrm{ml}): 84.2 \pm 27.8 ; 68.2 \pm 16.0 ; 63.6 \pm 23.1$, respectively. The PTH value was significantly greater $(p<0.05)$ in groups $B$ and $C$ in comparison with $A$, but no significant differences were observed between GB and GC. The $250 H$ D concentration was significantly less in GB $(p<0.05)$ and in GC $(p<0.01)$ in comparison with GA, showing no differences between GB and GC. A negative correlation between $25 \mathrm{OH}$ D and PTH was found $(r=-0.28 ; p=0.015)$. Conclusions. Data contributed by this study provide reference values for PTH 1-84 and 25OH D, evaluated using a third generation automated chemiluminescent method for PTH in local dogs. The results will facilitate monitoring diseases that alter the metabolism of calcium and phosphorus in dogs.
\end{abstract}

Key Words: Calcium, phosphorus, parathyroid hormone, metabolism, vitamin D (Source: MeSH).

\section{RESUMEN}

Objetivo. Aportar datos de referencia, para hormona paratiroidea 1-84 (PTH 1-84) y 25OH Vitamina D (25OH D) con una nueva técnica. Materiales y métodos. Las hormonas fueron valoradas, en suero, por un método quimioluminiscente automatizado, y de tercera generación para la PTH, en una población de 60 perros adultos clínicamente sanos, agrupados según edad en años en GA: 1 a 5, GB: 6 a 10 y GC: > 10. Resultados. Los datos expresados como media \pm DS fueron para la PTH (pg/ml): 9.3 \pm 2.3 ; $12 \pm 6.3 ; 12.2 \pm 3.7$; y para la $25 \mathrm{OH} \mathrm{D}(\mathrm{ng} / \mathrm{ml}): 84.2 \pm 27.8 ; 68.2 \pm 16.0 ; 63.6 \pm 23.1$, respectivamente. El valor de PTH fue significativamente mayor $(p<0.05)$ en los grupos $B$ y $C$ con respecto al $A$, pero no se observó diferencia significativa entre GB y GC. La concentración de 25OH D fue significativamente menor 
en el GB $(p<0.05)$ y en el GC $(p<0.01)$ con respecto al GA, sin haber diferencias entre los GB y GC. Se encontró una correlación negativa entre $250 \mathrm{OH}$ y PTH $(r=-0.28 ; p=0.015)$. Conclusiones. Los datos aportados en este trabajo permiten disponer de valores de referencia de PTH 1-84 y de $25 \mathrm{OH}$ $D$, valorados por un método quimioluminiscente automatizado y de tercera generación para la PTH, en una población local de perros. Los resultados facilitarán el seguimiento de enfermedades que alteran el metabolismo del calcio y fósforo en perros.

Palabras clave: Calcio, fósforo, hormona paratiroidea, metabolismo, vitamina D (Fuente: MeSH).

\section{INTRODUCTION}

The parathyroid hormone (PTH) is the one that controls the concentration of ionic calcium (iCa) in blood and extracellular liquid. Binding to membrane receptors on bone and kidney, it triggers a response that increases iCa; also, it stimulates the renal synthesis of $1.25(\mathrm{OH})_{2} \mathrm{D}_{3}$ (Calcitriol), the active form of Vitamin D. This acts through the specific receptors for Vitamin D (VDR) in the intestines; increasing the absorption of dietary calcium in bones and kidneys to induce the flow of calcium towards the blood.

The resulting increased serum calcium and 1.25 $(\mathrm{OH})_{2} \mathrm{D}_{3}$ exert a negative control on PTH synthesis and secretion in parathyroid cells. The increased blood phosphorus produces significant increases in the secretion of PTH $(1,2)$. Dogs ineffectively photosynthesize Vitamin $D$ through their skin, so that concentration depends on dietary intake and absorption through the intestines. Transported to the liver, it becomes 25-hydroxyvitamin D $(25 \mathrm{OH}$ $\mathrm{D}$ or Calcidiol), to be later hydroxylated in the renal proximal tubule to calcitriol via stimulation by PTH (2.3).

PTH is a peptide molecule with 84 amino acids, synthesized in cells of the parathyroid gland as a precursor of 115 amino acids called pre-proPTH. The pre and pro sequences are unfolded and degraded during their transit through the cisterns of the endoplasmic reticulum, and the hormone is stored in two types of secretory vesicles: some contain the intact molecule with 84 amino acids (PTH 1-84) which it is the biologically active form, and the others contain proteases that degrade the molecule generating different carboxyl-terminal fragments (PTH Ct) $(5,6)$. According to the extracellular concentration of iCa, parathyroid cells can secrete both PTH 1-84 and PTH Ct. iCa levels in the extracellular fluid are maintained within normal limits by a sensor calcium receptor (Ca-SR) coupled to a G protein located in the membrane of parathyroid cells. Low concentrations of extracellular iCa stimulate the secretion of PTH 1-84, and high levels of iCa activate Ca-SR which initiates an intracellular signaling cascade that culminates in the inhibition of biologically active PTH secretion

\section{INTRODUCCIÓN}

La hormona paratiroidea (PTH) es la encargada de controlar la concentración de calcio iónico (Cai) en sangre y líquido extracelular. Su unión a receptores de membrana, en el hueso y el riñón, desencadena una respuesta que aumenta el Cai; también, estimula la síntesis renal de $1.25(\mathrm{OH})_{2} \mathrm{D}_{3}$ (Calcitriol), la forma activa de vitamina D. Esta actúa, a través de receptores específicos para vitamina $D(V D R)$, en el intestino; aumentando la absorción del calcio dietario, y en el hueso y los riñones para inducir el flujo de calcio hacia la sangre. El consiguiente aumento del calcio sérico y de la $1.25(\mathrm{OH})_{2} \mathrm{D}_{3}$ ejercen un control negativo en la síntesis y secreción de PTH en las células paratiroideas. El aumento del fósforo en sangre produce importantes incrementos en la secreción de PTH $(1,2)$.

Los perros fotosintetizan en forma ineficaz la vitamina $D$ en su piel, por lo que su concentración depende de su ingesta en la dieta y su absorción por el intestino. Transportada hasta el hígado se transforma en 25-hidroxivitamina D (25OH D o Calcidiol), para luego ser hidroxilada en el túbulo proximal renal a calcitriol, vía estimulación por la PTH $(2,3)$.

La PTH es una molécula peptídica de 84 aminoácidos, sintetizada en las células de la glándula paratiroides como un precursor de 115 aminoácidos Ilamado pre-pro-PTH. Las secuencias pre y pro son desdobladas y degradadas, durante su tránsito a través de las cisternas del retículo endoplásmico, y la hormona es almacenada en dos tipos de vesículas secretorias: unas contienen la molécula intacta con sus 84 aminoácidos (PTH 1-84), que es la forma biológicamente activa, y las otras contienen proteasas que degradan la molécula generando distintos fragmentos carboxiterminales (PTH Ct) $(5,6)$. De acuerdo con la concentración extracelulares de Cai, las células paratiroideas son capaces de secretar tanto PTH 1-84 como PTH Ct. Los niveles de Cai en el líquido extracelular se mantienen dentro de la normalidad gracias a un receptor sensor de calcio (CaSR) acoplado a una proteína G localizada en la membrana de las células paratiroideas. Baja 
and increases PTH proteolysis. Accordingly, by increasing the concentration of extracellular iCa, the proportion of PTH Ct fragments secreted are increased (2,3-5). While it was believed that these fragments had no biological activity, it has been demonstrated in humans and animals that some PTH Ct fragments have an opposite effect on blood concentration of iCa (5-7).

PTH in plasma circulates at very low concentrations and the presence of circulating peptide fragments makes it difficult to measure. This situation presents a wide variability between methods of measurement.

The first generation of PTH analysis was done with radioimmunoassay, and the few sensitive and specific studies measured both the intact form and their fragments. Second generation immunoassays, called intact PTH analysis, have a system of two antibodies, one specifically for the carboxyl terminal portion and one for the amino terminal portion of the molecule. Initially it was believed that these methods only detected PTH 1-84. However, later studies showed that there are circulating PTH fragments which, being degraded in the amino terminal portion of the molecule, do not possess amino acids 1-7 that are responsible for the biological activity of the hormone. This PTH 7-84 molecule and other long PTH Ct fragments can be detected by some second generation immunoassay with different specificity. This produces a great variation in the results obtained using different methodologies, especially in samples of patients with kidney disease, which have higher proportion of serum PTH Ct due to decreased renal clearance $(1,2,5,7)$.

In recent years third generation immunoassays were developed that are more specific, and they do not detect PTH 7-84 fragments since the antibodies used in their design are directed against amino acids 1-7 of the molecule, so they confer less variability in measuring biologically active PTH $(1,2,5-7)$.

There are no previous reports of reference values in dogs with automated chemiluminescent method for $250 \mathrm{OH}$ and $\mathrm{PTH}$, and the latter with new third generation technology. The aim of this study was to measure both hormones in a population of clinically healthy adult dogs to obtain reference values.

\section{MATERIALS AND METHODS}

Study population. Sixty clinically healthy dogs were studied, both sexes, older than one year, between 5 and $50 \mathrm{~kg}$ of weight. The animals concentración de Cai extracelular estimulan la secreción de PTH 1-84; en cambio altos niveles de Cai activan el CaSR lo cual inicia una cascada de señalización intracelular que culmina con la inhibición de secreción de PTH biológicamente activa y aumento de proteólisis de PTH. En consecuencia, al aumentar la concentración de Cai extracelular aumenta la proporción de fragmentos PTH Ct secretados (2,3-5). Si bien se creía que estos fragmentos no tenían actividad biológica, se ha demostrado en humanos y animales que algunos fragmentos de PTH Ct tienen un efecto opuesto sobre la concentración de Cai en sangre (5-7).

En el plasma la PTH circula en concentraciones muy bajas y la presencia de fragmentos peptídicos circulantes dificulta su medición. Dicha situación plantea una amplia variabilidad entre los métodos de medición.

La primera generación de análisis de PTH fueron por radioinmunoensayos, estudios pocos sensibles y específicos, medían tanto la forma intacta como sus fragmentos. Los inmunoensayos de segunda generación, llamados análisis de PTH Intacta, poseen un sistema de dos anticuerpos, uno específico para la porción carboxi terminal y otro para la porción amino terminal de la molécula. Inicialmente se creía que estos métodos detectaban únicamente la PTH 1-84. Sin embargo, estudios posteriores demostraron que existen en circulación fragmentos de PTH que, al estar degradados en la porción aminoterminal de la molécula, no poseen los aminoácidos 1-7 responsables de la actividad biológica de la hormona. Esta molécula PTH 7-84 y otros fragmentos PTH Ct largos pueden ser detectados por algunos inmunoensayos de segunda generación con diferente especificidad. Esto produce una gran variación en los resultados obtenidos con distintas metodologías, especialmente en las muestras de los pacientes con enfermedad renal, que tienen mayor proporción de PTH Ct en suero, debido a la disminución de su depuración renal $(1,2,5,7)$.

En los últimos años se desarrollaron inmunoensayos de tercera generación, más específicos, que no detectan los fragmentos de PTH 7-84 ya que los anticuerpos utilizados en el diseño de los mismos están dirigidos contra los aminoácidos 1-7 de la molécula, por lo que confieren menor variabilidad en la medición de PTH biológicamente activa $(1,2,5-7)$.

No se han encontrado publicaciones previas de valores de referencia en perros con método quimioluminiscente automatizado, para $250 \mathrm{H}$ 
came from the city and province of Buenos Aires (latitude: $34^{\circ} 30^{\prime} \mathrm{S}$, longitude: $58^{\circ} 26^{\prime} \mathrm{W}$, altitude: 25 m.a.s.l.), they lived in spacious kennels with access to a yard and garden. The geoclimatic condition at the time the study was during the month of August (austral winter). The average amount of daily sunlight was $10 \mathrm{~h} 25 \mathrm{~min}$, with an average of $10 \mathrm{~h} 04 \mathrm{~min}$, an average heliophany of $4.2 \mathrm{~h} /$ day and average temperature $12.0 \pm 0.8^{\circ} \mathrm{C}$ (source: National Meteorological Service of Argentina). They were fed commercial feed with an adequate intake of calcium and phosphorus for their age and body condition.

\section{Experimental design}

Selecting clinically health animals. The criteria used were the absence of clinical signs, normal physical examination, and the evaluation of urine, blood count and serum biochemistry within the laboratory references.

Formation of study groups. They were divided into three groups according to age range in years: Group A (GA): 1-5, Group B (GB) of 6-10 and group $C(\mathrm{GC}):>10$. While each was formed of 10 males and 10 females, the data were analyzed without distinction by sex, because a preliminary assessment, at this writing, found no gender differences in age groups.

Collection and processing of samples for urine, general and endocrine biochemistry. Blood and urine samples were collected solids, $12 \mathrm{~h}$ fasting, in the morning ( 8 and $10 \mathrm{am}$ ). To determine the normality of the animals studied, a full analysis of total urine, protein / creatinine ratio of urine (UP/C), hemogram and serum biochemical measurements (with automated enzymatic colorimetric methods) of: total protein, albumin, urea, creatinine, AP, GPT (ALT) and GOT (AST), total calcium (Ca), inorganic phosphate $(\mathrm{Pi})$ was done. The $\mathrm{Ca}$ total value was corrected with the albumin by formula (Ca - Albumin + 3.5).

Measuring PTH and Vitamin D. The blood of each dog was centrifuged within 30 minutes of collection, and the serum was stored at $-20^{\circ} \mathrm{C}$ until processed. The PTH 1-84 measurement was by third generation chemiluminescence (DiaSorin Liaison) with functional sensibility: $4.0 \mathrm{pg} / \mathrm{ml}$; $100 \%$ specificity for PTH 1-84 and 0\% crossed reactivity for PTH 7-84 and other fragments; with coefficient variation (CV) intra-essay at $6 \%$ and $\mathrm{CV}$ inter-essay at $9 \%$.

The total $250 \mathrm{H}$ D measurement was also done by chemiluminescence (DiaSorin Liaison) with a functional sensibility of $4.0 \mathrm{ng} / \mathrm{ml}, 100 \%$ specificity for $25-\mathrm{OH}$ Vitamin $\mathrm{D}_{2}$ and $25-\mathrm{OH}$
D y PTH y esta última con una nueva técnica de tercera generación. El objetivo del presente trabajo fue medir ambas hormonas en una población de perros adultos clínicamente sanos para obtener valores de referencia.

\section{MATERIALES Y MÉTODOS}

Población de estudio. Se estudiaron 60 perros clínicamente sanos, de ambos sexos, mayores a 1 año, que tenían entre 5 y $50 \mathrm{~kg}$ de peso. Los animales procedieron de la ciudad y provincia de Buenos Aires (latitud: 34030'S, longitud: 58026'W, altitud: 25 m.a.s.l.), vivían en caniles amplios con acceso a patio y jardín. La condición geoclimática en el momento de realizar el estudio fue durante el mes de agosto (invierno austral). La cantidad promedio de horas luz (solar) fue de 10 h 25 min, con promedio de 10 h 04 min, una media de heliofanía efectiva de 4.2 h/día y temperatura media $12.0 \pm 0.8^{\circ} \mathrm{C}$ (fuente: Servicio Meteorológico Nacional Argentina). Se alimentaron con balanceado comercial con un aporte de calcio y fósforo adecuado según edad y condición corporal.

\section{Diseño Experimental}

Selección de animales clínicamente sanos. Los criterios que se utilizaron fueron la ausencia de signos clínicos, examen físico sin alteración, y evaluación de orina, hemograma y bioquímica sérica dentro de los intervalos de referencia del laboratorio.

Formación de grupos de estudio. Se los dividió en tres grupos según rango etario, en años: Grupo A (GA): de 1-5, grupo B (GB): de 6 a 10 y grupo $C$ (GC): > 10. Si bien cada uno fue conformado por 10 machos y 10 hembras, los datos se analizaron sin distinción por sexo, debido a que una evaluación preliminar, al presente escrito, no halló diferencias por género en los grupos etarios.

Obtención y procesamiento de las muestras para: orina, bioquímica general y endócrina. Se recolectaron muestras de sangre y orina, en ayuno de sólidos de $12 \mathrm{~h}$, durante la mañana ( 8 y 10 am). Para determinar la normalidad de los animales estudiados se realizó análisis de orina completa, relación proteína/creatinina en orina (UP/C), hemograma y mediciones bioquímicas en suero (por métodos enzimáticos colorimétricos automatizados) de: proteínas totales, albúmina, urea, creatinina, FAS, GPT (ALT) y GOT (AST), Calcio total $(\mathrm{Ca})$, fósforo inorgánico(Pi). El valor de Ca total fue corregido con el de la albúmina mediante la fórmula ( $\mathrm{Ca}$ - Albúmina + 3.5). 
Vitamin $D_{3}$ and $1.3 \%$ crossed reactivity with 3-epi 25-OH Vitamin $\mathrm{D}_{3}$; CV intra-essay at 3.9\% and $\mathrm{CV}$ inter-essay at $9.8 \%$.

Processing site. Samples for general biochemistry were processed at the Teaching Hospital Laboratory, Faculty of Veterinary Medicine, University of Buenos Aires. The hormone measurement was performed at the Laboratory of the Endocrinology Division of the Hospital General de Agudos Carlos G. Durand.

Ethic approval. The Committee on Animal Welfare of the Faculty of Veterinary Medicine, UBA, approved the CICUAL N 2013/3 procedure subsidized by UBACyt 2011/2014 V-05.

Statistical analysis. The distribution of variables was analyzed with the D'Agostino and Pearson Test. Because PTH and Pi did not show a normal distribution, all variables were normalized transforming them into the logarithmic form, allowing, in this way, using one way ANOVA parametric tests followed by the Bonferroni test for multiple comparison of means to compare the three age groups. The variables were correlated using Pearson's test. To obtain minimum and maximum values, 3 and 97 percentiles were calculated.

The values are expressed in natural form (anti logarithmic) as mean \pm DS, and the minimum values (percentile 3 ) and maximum (Percentile 97). The selected level of meaning was $p<0.05$.

\section{RESULTS}

The values obtained for calcium $(\mathrm{mg} / \mathrm{l})$ were: median 10.9, with a range between 8.8 and 12 , and for phosphorus (mg/dl) median 4.2, with a range between 2.2 and 5.5 . They remain within the reference values for the laboratory, and no differences between age groups ( $p=0.1 \mathrm{Ca}$ and $\mathrm{Pi}, \mathrm{p}=0.3$ ) were found.

For PTH significant differences between the three groups studied $(p=0.04)$ were found, increasing significantly $(p \leq 0.05)$ in groups $B$ and $C$ compared to GA. No differences between $G B$ and GC (Figure 1) were found.

For $250 \mathrm{H}$ D significant differences were also found between the three groups $(p=0.005)$. Contrary to what happens with PTH, the concentration of this hormone decreases significantly in GB $(p \leq 0.05)$ and $G C(p \leq 0.01)$ compared to $G A$, with no difference between groups $B$ and $C$ (Figure 1 ).
Medición de PTH y vitamina D. La sangre de cada perro fue centrifugada, dentro de los 30 minutos de obtenida, y el suero fue almacenado a - $20^{\circ} \mathrm{C}$ hasta su procesamiento. La medición de PTH 1-84 fue por quimioluminiscencia de tercera generación (DiaSorin Liaison) con sensibilidad funcional: $4.0 \mathrm{pg} / \mathrm{ml}$; especificidad de $100 \%$ para PTH 1-84 y $0 \%$ de reactividad cruzada para PTH 7-84 y otros fragmentos; con coeficiente de variación (CV) intra-ensayo de $6 \%$ y CV interensayo de $9 \%$.

La medición de $250 H$ D total se realizó, también, por quimioluminiscencia (DiaSorin Liaison), con una sensibilidad funcional de $4.0 \mathrm{ng} / \mathrm{ml}$, especificidad de $100 \%$ para $25-0 H$ Vitamina $D_{2}$ y $25-\mathrm{OH}$ vitamina $\mathrm{D}_{3}$ y $1.3 \%$ de reactividad cruzada con 3-epi $25-\mathrm{OH}$ vitamina $\mathrm{D}_{3}$; $\mathrm{CV}$ intra-ensayo de $3.9 \%$ y CV inter-ensayo de $9.8 \%$.

Sitio de procesado. Las muestras para bioquímica general se procesaron en el Laboratorio del Hospital Escuela de la Facultad de Medicina Veterinaria, Universidad de Buenos Aires. La medición de las hormonas se realizó en el Laboratorio de la División Endocrinología del Hospital General de Agudos Carlos G. Durand.

Aprobación ética. El comité de Bienestar animal de la Facultad de Medicina Veterinaria, UBA, aprobó el procedimiento CICUAL N 2013/3 de subsidio UBACyt 2011/2014 V-05.

Análisis estadístico. La distribución de las variables se analizó con el Test de D'Agostino y Pearson. Debido a que la PTH y el Pi no mostraron una distribución normal, todas las variables fueron normalizadas transformándolas a su forma logarítmica, permitiendo, de esta manera, utilizar las pruebas paramétricas ANOVA de una vía, seguido por el test de Bonferroni de múltiple comparación de medias, para comparar los tres

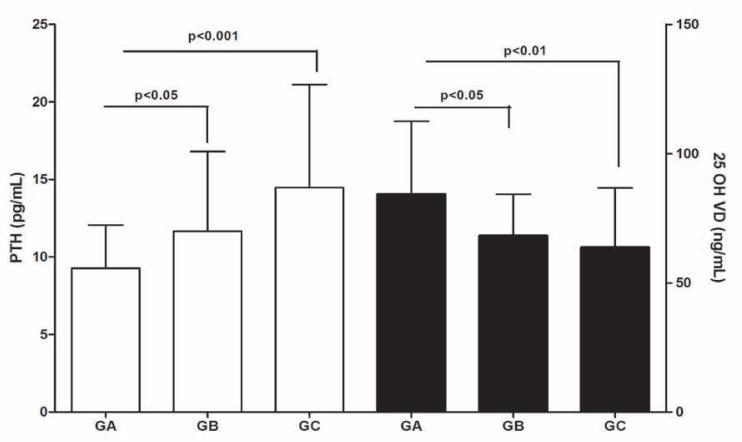

Figure 1. Concentration of PTH and $250 \mathrm{OH}$, in dogs, by the third generation automated chemiluminescent method for PTH according to age groups. An increase in PTH is observed with a decrease in $250 H \mathrm{D}$ in dogs older than 5 years.

Group A (GA): 1-5, Group B (GB): 6-10 years and Group C (GC): older than 10 years. 
The $250 H$ D had a negative and weak correlation with the $\mathrm{PTH}$ in a significant way $(r=-0.28$; $\mathrm{p}=0.015$ ) (Figure 2).

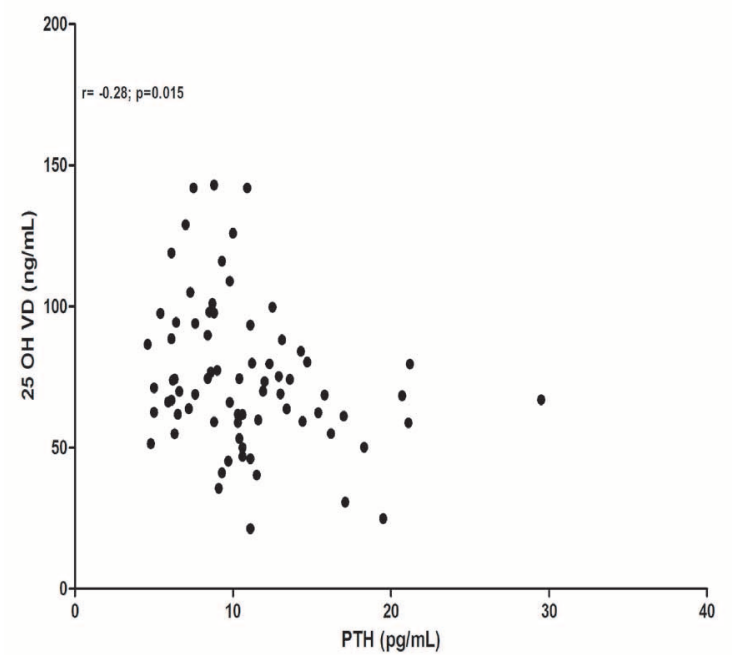

Figure 2. Correlation between $25-\mathrm{OH}$ D vs PTH, evaluated by the by the third generation automated chemiluminescent method for PTH, in dogs. As the PTH increases there is a decrease in the 25-OH D.

No correlation was observed between the hormones studied and the concentration of $\mathrm{Ca}$ and $\mathrm{Pi}$.

PTH and 25OH-D values, expressed as median and minumun-maximun according to the group, are showed in the table 1

Table 1. PTH and 25-OH D values by the third generation automated chemiluminescent method for PTH, in dogs, expressed in mean and interval (values by Percentile 3 and 97 cuts) according to age group.

\begin{tabular}{ccccccc}
\hline & \multicolumn{2}{c}{ Group A } & \multicolumn{2}{c}{ Group B } & \multicolumn{2}{c}{ Group C } \\
& mean & P3-P97 & mean & P3 -P97 & mean & P3 - P97 \\
\hline $\begin{array}{c}\text { PTH } \\
(\mathrm{pg} / \mathrm{mL})\end{array}$ & 8.8 & $5-15.3$ & 10.3 & $5-21.2$ & 12.4 & $6.3-32.3$ \\
$\begin{array}{c}\mathbf{2 5 O H} \mathbf{D} \\
(\mathrm{ng} / \mathrm{mL})\end{array}$ & 75.5 & $45.3-143$ & 67 & $35.6-98$ & 66.7 & $21.3-109$ \\
\hline
\end{tabular}

Group A (GA): 1-5, Group B (GB): 6-10 years and Group C (GC): older than 10 years.

\section{DISCUSSION}

The few publications that evaluate PTH in clinically healthy dogs were performed with different methodologies than those used in this study. Some used IRMA (8.9) and other second-generation chemiluminescence (using a grupos etarios. Las variables se correlacionaron por medio de la prueba de Pearson. Para obtener valores mínimos y máximos se calcularon los percentiles 3 y 97.

Los valores se expresan en su forma natural (anti logarítmica) como media \pm DS, y los valores mínimos (percentil 3) y máximos (Percentil 97). El nivel de significación seleccionado fue de $p<0.05$.

\section{RESULTADOS}

Los valores obtenidos para el calcio ( $\mathrm{mg} / \mathrm{l}$ ) fueron: mediana 10.9, con intervalo entre 8.8 y 12, y para el fósforo ( $\mathrm{mg} / \mathrm{dl}$ ) mediana: 4.2, con intervalo entre 2.2 y 5.5 . Estando dentro de los valores de referencia para el laboratorio, no se hallaron diferencias entre los grupos etarios ( $\mathrm{Ca}$ $\mathrm{p}=0.1$ y $\mathrm{Pi}, \mathrm{p}=0.3$ ).

Para la PTH se hallaron diferencias significativas entre los 3 grupos estudiados $(p=0.04)$, aumentando significativamente $(p \leq 0.05)$ en los grupos B y C con respecto al GA. No se hallaron diferencias entre el GB y GC (Figura 1).

Para la 250H D, también, se hallaron diferencias significativas entre los tres grupos $(p=0.005)$. Contrariamente a lo que sucede con la PTH, la concentración de esta hormona disminuye significativamente en el GB $(p \leq 0.05)$ y en el GC $(p \leq 0.01)$ respecto del $G A$, sin diferencias entre los grupos B y C (Figura 1 ).

La $250 H$ D correlacionó negativa y débilmente con la PTH en forma significativa $(r=-0.28$; $p=0.015$ ) (Figura 2).

No se observó correlación entre las hormonas estudiadas y la concentración del Ca y $\mathrm{Pi}$.

Los valores de PTH y $250 \mathrm{H}$, expresados en mediana y valores máximos y mínimos, según grupo etario, se muestran en la tabla 1.

\section{DISCUSIÓN}

Las escasas las publicaciones que valoran PTH en perros clínicamente sanos se realizaron con diferentes metodologías al presente estudio. Unos fueron mediante IRMA $(8,9)$ y otros por quimioluminiscencia de segunda generación (utilizan un sistema de 2 anticuerpos: uno dirigido contra un epítope en la región Ct y otro contra la región Nt de la molécula (aminoácidos 1-34), mide PTH intacta y fragmentos NO 1-84) $(1,8,7,10-12)$. 
system of two antibodies, one directed against an epitope in the $\mathrm{Ct}$ region and another against the Nt region of the molecule (amino acids 1-34), measuring intact PTH and NO fragments 1-84) $(1,8,7,10-12)$.

In this study an automated third generation chemiluminescence method was used (AC directed against the $\mathrm{Nt}$ region of $\mathrm{PTH}$, specific for amino acids 1-4 of the molecule, this allows avoiding cross-reactions with PTH peptides that have the same biological activity, particularly PTH 7-84, so only intact PTH values are evaluated) (13). The quality of avoiding interference of the fragments make it of special interest in chronic renal failure, as they accumulate in the blood by decreasing glomerular filtration, since the kidney is responsible for cleansing the urine $(2,6,7)$.

A third generation model was used by Machado and Moutinho (14) in dogs, but they concluded that it was not useful to evaluate PTH. Pineda et al (15) were able to measure it in cats with a manual technique, which required 2 successive measurements per sample.

The discrepancy in the results reported by other authors and in this study result from intermethod variability that cannot be correctly compared. However, they provide higher maximum values than this study, possibly due to not only measuring active PTH (8-14).

The decrease in glomerular filtration that occurs with age decreases urine phosphorus elimination, and consequently it increases in the blood, followed by a decrease in serum calcium. Although both ions are kept within the range of reference serum, this situation stimulates the synthesis and secretion of PTH. This physiological variation explains the slight increase in PTH levels observed in dogs older than 5 years (GB and GC) and agrees with the results found by Aguilera-Tejero et al (8) in a study with another methodology PTH and found in a population of clinically healthy dogs over 10 years.

PTH results obtained in this study are similar to those reported in human medicine with the same method, which also observed higher values in the elderly such as those found in GB and GC $(2,16)$.

The variability in PTH results is related to the clinical condition of the patient (primary and secondary conditions of the parathyroid) and are based on pre-analytical and analytical biological conditioning. The first is inherent in handling samples, considering that circulating PTH concentration varies throughout the day (circadian rhythm, intake of calcium and
En este trabajo se utilizó un método por quimioluminiscencia, automatizado, de tercera generación (el Ac dirigido contra la región Nt de la PTH, es específico para los aminoácidos 1-4 de la molécula, esto le permite evitar reacciones cruzadas con péptidos de PTH que no tienen la misma actividad biológica, especialmente la PTH 7-84, de esta manera sólo valora PTH intacta) (13). La cualidad de evitar la interferencia de los fragmentos la hacen de especial interés en la insuficiencia renal crónica, ya que éstos se acumulan en sangre al disminuir el filtrado glomerular, por ser el riñón el encargado de depurarlos por orina $(2,6,7)$.

Un método de tercera generación fue utilizado por Machado y Moutinho (14) en perros, pero concluyeron que no era útil para valorar $\mathrm{PTH}$. Pineda et al (15) lograron medirla en gatos con una técnica manual, que necesita realizar 2 mediciones sucesivas por muestra.

La discrepancia en los resultados aportados por otros autores y por el presente trabajo resultan de una variabilidad intermétodo, que no permite compararlos correctamente. Sin embargo, aportan valores máximos más elevados al presente estudio; lo que posiblemente se deba a que no sólo miden PTH activa (8-14).

La disminución del filtrado glomerular, que se produce con la edad, disminuye la eliminación del fósforo por orina, y consecuentemente aumenta en sangre seguido de una disminución de la calcemia. Aunque ambos iones se mantienen dentro del intervalo de referencia sérica, dicha situación estimula la síntesis y secreción de PTH. Esta variación fisiológica explicaría el ligero aumento de los valores de PTH que se observa en perros mayores de 5 años (GB y GC) y concuerda con los resultados encontrados por Aguilera-Tejero et al (8) en un estudio realizado con otra metodología de PTH y hallados en una población de perros clínicamente sanos mayores de 10 años.

Los resultados de PTH obtenidos en este estudio son similares a los reportados en medicina humana con el mismo método, donde también fueron observados valores más altos en ancianos como los hallados en el GB Y GC $(2,16)$.

La variabilidad en los resultados de la PTH está relacionada con la situación clínica del paciente (afecciones primarias y secundarias de las paratiroides) y en función de condicionamientos biológicos, pre-analíticos y analíticos. Los primeros son inherentes al manejo de la muestra, hay que considerar que la concentración circulante de PTH varía a lo largo del día (ritmo 
phosphorus, etc.) $(1,2,5,8,17)$. To minimize these changes, it is advisable to remove the blood sample at the same time of day and under the same conditions. Also, there are differences in the results of PTH according to the serum, plasma, type of anticoagulant, time and storage method of the sample. Intact PTH concentration decreases starting at $24 \mathrm{~h}$ at temperatures of $18-25^{\circ} \mathrm{C}(1,2)$.

Veterinary measurements with a second generation method were performed on plasma $(8-10,18)$. In this study, pre-analytical conditions that guarantee the stability of the sample from blood collection to processing were established, thereby minimizing errors inherent in sample preservation.

The level of vitamin D sufficiency is evaluated in human medicine, through $250 \mathrm{H}$, with an expected desirable value, at present, greater than $30 \mathrm{ng} / \mathrm{ml}$ (reserving 1-25 OH D measurements to exceptional cases), and is considered insufficient between 20 and 29 (commonly found in older adults $\geq 70$ years) and poor $<19 \mathrm{ng} / \mathrm{ml}$ (2.19). A similar situation was observed in our study where values $>30$ $\mathrm{ng} / \mathrm{ml}$ were found in groups $A$ and $B$, with the lowest value ( 3 rd percentile) below $30 \mathrm{ng} / \mathrm{ml}$ for the group $\mathrm{C}$. This finding determined that the lower value in dogs older than 10 years is $20 \mathrm{ng} / \mathrm{ml}$; or three dogs that were within this value could be considered insufficient. The few studies that evaluate vitamin $D$ in dogs found no differences with age (8), although the method of measurement was different to that used in the present work.

The lowest concentration of $250 \mathrm{OH}$ observed in elderly humans is explained by skin aging and less exposure to the sun, among other causes (2). This explanation would not be extrapolated to dogs because they ineffectively photosynthesize vitamin $D$ in their skin, so that its concentration depends on dietary intake and absorption through the gut (18$20)$. In any case, our study population had adequate sun exposure. All the dogs ate the same food to avoid variations in intake, which is why intestinal absorption dysfunction would be a possible cause of the differences found between groups. The reduced concentration of $250 H \mathrm{D}$ in older dogs in the study population was reflected by increased PTH to maintain calcium and phosphorus metabolism, since the decline in vitamin $D$ decreases the inhibitory effect on PTH $(1,2)$.

In conclusion, the contribution of PTH reference intervals with a third generation method circadiano, ingesta de calcio y fósforo, etc.) $(1,2,5,8,17)$. Para minimizar dichos cambios es aconsejable extraer la muestra de sangre al paciente en el mismo momento del día y en iguales condiciones. También, existen diferencias en los resultados de PTH de acuerdo a si se utiliza suero, plasma, tipo de anticoagulante, el tiempo y modo de conservación de la muestra. La concentración de PTH intacta disminuye a partir de las $24 \mathrm{~h}$ a temperatura de $18-25^{\circ} \mathrm{C}(1,2)$.

Las mediciones en veterinaria con el método de segunda generación fueron realizadas en plasma $(8-10,18)$. En este trabajo se establecieron condiciones preanalíticas que garantizan la estabilidad de la muestra desde la extracción de sangre hasta su procesamiento, minimizando así los errores inherentes a la conservación de la muestra.

El nivel de suficiencia de vitamina $D$ es valorado, en medicina humana, a través de la $250 \mathrm{OH}$, con un valor deseable esperado, en la actualidad, mayor de $30 \mathrm{ng} / \mathrm{ml}$ (reservando la medición de 1-25 $\mathrm{OH}$ D para casos excepcionales), y se considera insuficiente entre 20 y 29 (hallazgo frecuente en adultos ancianos $\geq 70$ años), y deficiente $<$ de 19 $\mathrm{ng} / \mathrm{ml}(2,19)$. Similar situación fue observada en nuestro estudio donde se encontraron valores $>$ de $30 \mathrm{ng} / \mathrm{ml}$ en los grupos A y B, siendo el valor inferior (percentil 3) menor de $30 \mathrm{ng} / \mathrm{ml}$ para el grupo C. Dicho hallazgo determinaría que el valor inferior en perros mayores de 10 años sea $20 \mathrm{ng} / \mathrm{ml}$; o los tres perros que se encontraron dentro de este valor podrían ser considerados como insuficientes. Los escasos estudios que valoran la vitamina $D$ en el perro no encontraron diferencias con la edad (8), aunque el método de medición fue diferente al utilizado en el presente trabajo.

La menor concentración de $250 \mathrm{OH}$ observada en humanos ancianos se explicaría por envejecimiento de la piel y menor exposición al sol entre otras causas (2). Esta explicación no sería extrapolable al perro, porque ellos fotosintetizan en forma ineficaz la vitamina $D$ en su piel, por lo que su concentración depende de su ingesta en la dieta y su absorción por el intestino (18-20). De todas formas nuestra población de estudio tuvo una exposición solar adecuada. Todos los perros comieron el mismo tipo de alimento para evitar variaciones por la ingesta, motivo por el cual una disfunción en la absorción intestinal sería una posible causa de las diferencias halladas entre grupos. La disminución de la concentración de $250 \mathrm{OH}$ en los perros de mayor edad, en la población de estudio, se vio reflejada con un incremento de la PTH, para mantener el metabolismo fosfocálcico, debido a que el descenso de la vitamina $D$ disminuye el efecto inhibitorio sobre la PTH $(1,2)$. 
and $250 \mathrm{H}$ D in dogs, both by automated chemiluminescent technique, will be used to study diseases that alter calcium and phosphorus metabolism. This is the first report classified by age and where both hormones are correlated. In dogs older than 5 years, it is expected to find values of calcium and phosphorus in normal reference ranges with a physiological increase of PTH to counteract declining $250 \mathrm{H}$ D.

\section{Acknowledgment}

Project CV-05, subsidized by UBACyT 2011/2014.
En conclusión el aporte de los intervalos de referencia de $\mathrm{PTH}$, con un método de tercera generación y de $250 \mathrm{H}$ D en perros, ambas mediante técnica quimioluminiscente automatizada, servirán para estudiar a las enfermedades que alteran el metabolismo fosfocálcico. Este sería el primer reporte estadificado por edad, y en donde se correlacionan ambas hormonas. En perros mayores de 5 años es de esperar encontrar valores de calcio y de fósforo en intervalos de referencia normales con un incremento fisiológico de PTH para contrarrestar el descenso de $250 \mathrm{H}$ D.

\section{Agradecimientos}

Proyecto CV-05, subsidiado por UBACyT 2011/2014

\section{REFERENCES}

1. Feldman E, Nelson R. Hipercalcemia e hiperparatiroidismo primario, hipocalcemia e Hipoparatiroidismo. Endocrionología y Reproducción Canina y Felina, 3ed, Editorial Intermédica 2007.

2. Cannata AJ. Alteraciones del metabolismo óseo y mineral en la enfermedad renal crónica: avances en patogenia, diagnóstico y tratamiento. España: Wolters Kluwer Health España, S.A; Lippincott Williams \& Wilkins; 2010.

3. Schropp K. Phosphorous and phosphate metabolism in veterinary patients. J Vet Emerg Crit Care 2006; 17:127-134.

4. How KL, Hazewinkel $\mathrm{H}, \mathrm{MOL} \mathrm{JA}$. Dietary Vitamin D Dependence of Cat and Dog Due to Inadequate Cutaneous Synthesis of Vitamin D. Gen Comp Endocrinol 1994; 96(1):12-18.

5. Friedman PA, Goodman WA, PTH (1-84)/ PTH (7-84): a balance of power. Am J Renal Physiol 2006; 290:F975-F984.

6. Murray TM, Rao L, Divieti P, Bringhurst RF. Parathyroid Hormone Secretion and Action: Evidence for Discrete Receptors for the Carboxyl-Terminal Region and Related Biological Actions of Carboxyl- Terminal Ligands. Endocr Rev 2005; 26(1):78-113.
7. Sturgeon C, Sprague SM, Metcalfe W. Variation in parathyroid hormone immunoassay results-a critical governance issue in the management of chronic kidney disease. Nephrol Dial Transplant 2011; 26:3440-3445.

8. Aguilera-Tejero E, Lopez-Estepa JC, Mayyer-Valor $R$, Almadén $Y$, Concepción MT, Felsenfela AJ, Rodriguez M. Mineral metabolism in healthy geriatric dogs. Res Vet Sci 1998; 64:191-94.

9. Torrance AG, Nachreiner R. Intact parathyroid hormone assay and total calcium concentration in the diagnosis of disorders of calcium metabolism in dogs. J Vet Intern Med 1989; 3:86-89.

10. Torrance AG; Nachreiner R. Human parathormone assay for use in dogs: Validation, sample handling studies, and parathyroid function testing. Am J Vet Res 1989; 50:1123/1127.

11. Graham KJ, Wilkinson M, Culvenor J, Dhand NK, Churchera RK. Intraoperative parathyroid hormone concentration to confirm removal of hypersecretory parathyroid tissue and time to postoperative normocalcaemia in nine dogs with primary hyperparathyroidism. Aust Vet J 2012; 90(6):203-209. 
12. Kathleen $\mathrm{H}$, Greenfield $C$, Barger A, Schaeffer D, Ehrhart E, Pinkerton M, Valli V. Validation of a rapid parathyroid hormone assay and intraoperative measurement of parathyroid hormone in dogs with benign naturally occurring primary hyperparathyroidism. Vet Surg 2009; 38:122-132.

13. de La Piedra C, Fernández E, González Casaus L, González Parra E. Diferencias en la función de los péptidos paratiroideos. ¿Qué estamos midiendo? Nefrología 2008; 28(2):123-128.

14. Machado LHA, Moutinho FQ. Validação do método de quimioluminescência para determinação de PTH intacto em cães. Vet Zootec 2013; 20(1):84-90.

15. Pineda C, Aguilera-Tejeroa E, Raya A, Diez E, Rodriguez M, Lopez I. Feline parathyroid hormone: validation of hormonal assays and dynamics of secretion. Domest Anim Endocrinol 2012; 42:256-264.

16. Kogovsek N; Lacaze N; Theaux C; Salerni E; Mormando E; Astarita G; Bernatene D; Anzil O; Oero P. Comparación de tres metodologías para la medición de la Hormona Paratiroidea. Acta Bioquím Clín Latinoam 2012; 46(3):507-11.
17. López I, Aguilera-Tejero E, Estepa JC, Bas $S$, Mayer-Valor $R$, Jiménez $A$, Rodríguez M. Diurnal variations in the plasma concentration of parathyroid hormone in dogs. Vet Rec 2005; 157(12):344-347.

18. Suarez-Rey ML. Manejo de la enfermedad renal crónica. REDVET 2007; 2(1):1-18.

19. Mastaglia SR, Watson DZ, Oliver B. Controversia sobre los niveles adecuados de Vitamina D para la salud ósea propuestos por el instituto de medicina de los Estados Unidos y la comunidad médica internacional. Actual Osteol 2013; 9(2):207-16.

20. Allen T, Polzin D, Adams L. Renal Disease. Small Animal Clinical Nutrition, $4^{\text {th }}$ edition. Chapter 19. Estados Unidos: Mark Morris Institute; 2000.

21. Bonagura JD, Twedt DC. Terapéutica Veterinaria Actual XIV. Madrid, España: Elsevier; 2009. 